INTERDISCIPLINARIA ARCHAEOLOGICA NATURAL SCIENCES IN ARCHAEOLOGY

\title{
Some Examples of Good Practice in LiDAR Prospection in Preventive Archaeology
}

\author{
Milan Horňák ${ }^{\mathrm{a}^{*}}$, Ján Zachar ${ }^{\mathrm{a}}$ \\ ${ }^{a}$ VIA MAGNA, s. r. o. Nábrežná 2, 03861 Vrútky, Slovakia
}

\section{ARTICLE INFO}

\section{Article history:}

Received: $28^{\text {th }}$ February 2017

Accepted: $11^{\text {th }}$ September 2017

DOI: http://dx.doi.org/ 10.24916/iansa.2017.2.1

\section{Key words:}

LiDAR

hillshade

topographic openness

sky view factor

hillfort

classification

preventive archaeology

\begin{abstract}
$A B S T R A C T$
The prime objective of this article is to demonstrate the possibilities of LiDAR mapping in the field of preventive archaeology. The article focuses upon detailed descriptions of case studies that present particular examples of LiDAR application possibilities, as well as its limitations. The final remarks sum up an appropriate procedure for LiDAR prospection when applied to preventive archaeology and cultural heritage.
\end{abstract}

\section{Introduction}

Unlike more generally in Europe, where LiDAR has been applied in many archaeological projects over recent years (e.g. Bofinger, Hesse 2011; Challis et al. 2011; Devereux et al. 2008; Doneus, Briese 2006; 2011; Doneus et al. 2008; Hesse 2010; Gojda, John 2013; Opitz, Cowley 2013; Štular et al. 2012; Trier, Pilo 2002 etc.), the potential of airborne laser scanning has been much neglected within Slovakian archaeology over the same period. Apart from some very rare articles on this topic (Ruttkay 2015; Holubec et al. 2016), no complex systematic studies, or even local particular archaeological projects, have been carried out (M. Ruttkay's study contains just brief visual description of LiDAR data on particular hillforts in Nitra region. No information on ground points filtering algorithm and DEM creation parameters is provided. Furthermore, besides basic analytical hillshading, no further visualisation methods are applied. Graphic vector interpretation is also missing. The study of M. Holubec et al. deals with LiDAR documentation of the Iron Age hillfort Molpír in southwest Slovakia. It focuses mainly upon the

*Corresponding author. E-mail: hornak.milan@gmail.com possibilities of morphometric analysis by the detection of small anthropomorphic features. For this purpose algorithms aimed at visual augmentation of concave and convex surface shapes were tested). This is also partly due to the fact that in Slovakia, unlike some European countries, no public LiDAR data are available - either in point-cloud format or as DEM products. Although in many European countries LiDAR data are also not publicly available, in most cases they are at least partly accessible commercially. Furthermore, a significant part of the territory has not been covered with LiDAR survey at all. One of the aims of this article is to present particular case studies of LiDAR application on various types of archaeological sites in the Turiec region, Slovakia (Figure 1), with the intention to examine the potential of LiDAR in archaeological cultural heritage protection and encourage further development of LiDAR studies.

\section{Methods}

The LiDAR data acquisition of individual test areas were performed at the end of March 2016. For the scanner, a Leica ALS70-CM mounted on the light airplane Cessna 402 


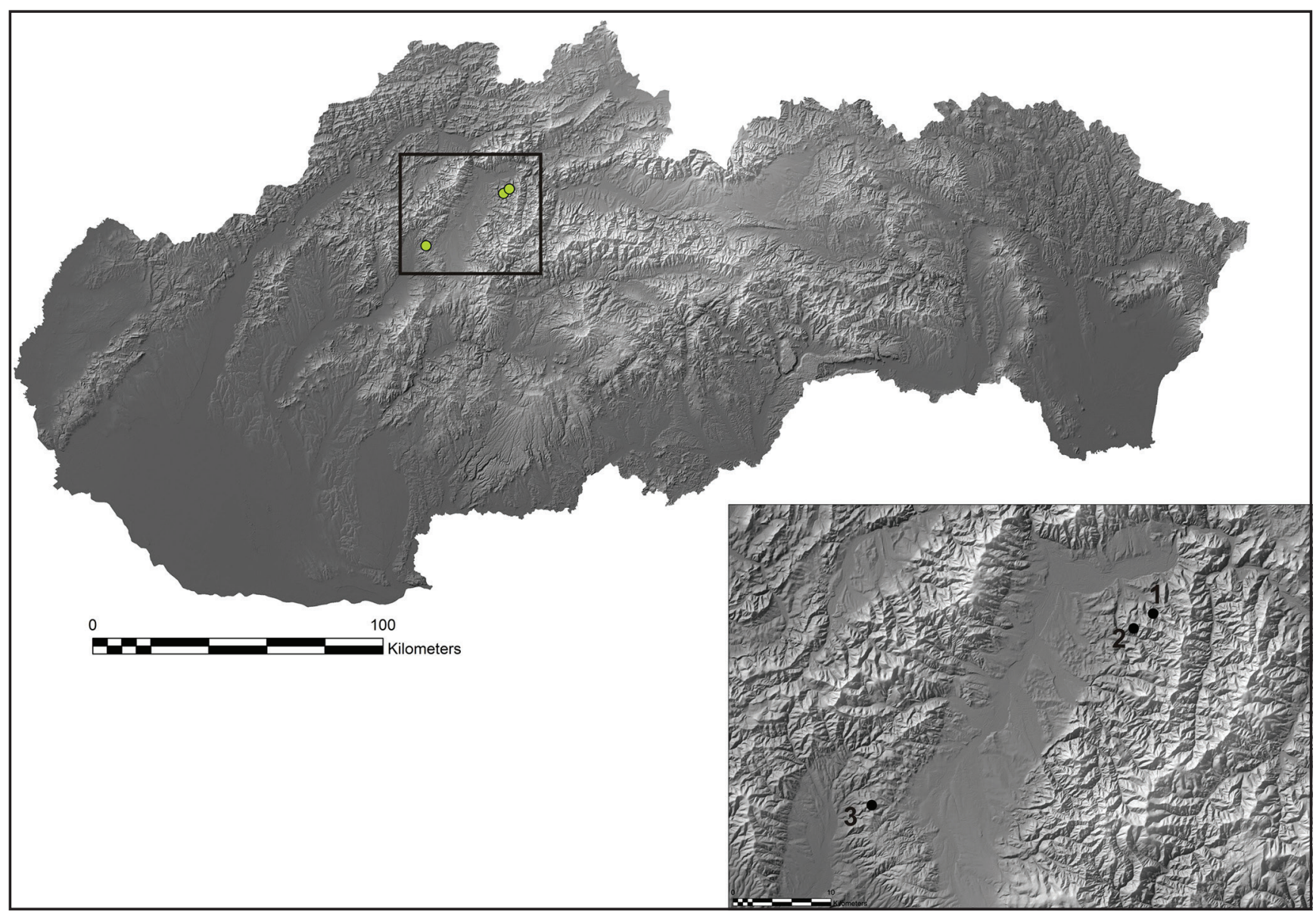

Figure 1. Location of the case study sites. 1: Podhradie-Vrchmúr, 2: Sklabinský Podzámok - hillfort "Katova Skala", 3: Jasenové/Nitrianske Pravno hillfort "Vyšehrad"

was used (Field of View /FOV/: 36 ${ }^{\circ}$, Scan Rate Setting used (SR): $\max 56 \mathrm{~Hz}$, Maximum Laser Pulse Rate: $328400 \mathrm{~Hz}$, Horizontal accuracy: $0.06 \mathrm{~m}$, Vertical accuracy: $0.08 \mathrm{~m}$ ).

The open-source software CloudCompare with the Cloth Simulation Filter (CSF) plugin ${ }^{1}$ was applied for the filtering (classification) of unclassified data. The principle of the algorithm is that the original point cloud is turned upside down, and then a virtual „,cloth“ is draped upon the inverted surface from above. By analyzing the interactions between the nodes of the cloth and the corresponding LiDAR points, the final shape of the cloth can be determined and used as a baseline to classify the original points into ground and non-ground parts (for a better notion of the algorithm see: Zhang et al. 2016). The choice of the optimal parameters

\footnotetext{
${ }^{1}$ http://www.cloudcompare.org/
}

with respect to the landscape's specific features was crucial, as it determined the amount of detected ground points and subsequently the global quality of the final digital elevation model (DEM) represented by a digital terrain model $(\mathrm{DTM})^{2}$. As all of the inspected sites are situated in a mountainous region with a highly closed tree canopy, the adopted parameters had to respect this determination. Out of the „scene“ options (flat, relief, steep slope) that the software offered, the „steep slope“ alternative performed the best as all tested sites represent hilly environments with slopes up to 60 degrees in steepness. Moreover, the software offered advanced parameters that enable a further precision

\footnotetext{
${ }^{2}$ In this article we use DEM as a general expression, whereas DTM (digital terrain model) refers to the terrain model generated purely out of ground points in contrast to DSM (digital surface model) representing a model of the whole surface created out of all points.
}

Table 1. Data of classification/ filtration procedure.

\begin{tabular}{lcrrrc}
\hline Site & Documented area & Nr. of all points & Nr. of ground points & $\begin{array}{c}\text { All points } \\
\text { density }\end{array}$ & $\begin{array}{c}\text { Ground points } \\
\text { density }\end{array}$ \\
\hline Podhradie-Vrchmúr & $0.04 \mathrm{~km}^{2}$ & $5,778,119$ & $1,190,931(21 \%)$ & $180 / \mathrm{m}^{2}$ & $38 / \mathrm{m}^{2}$ \\
Skl. Podzámok-Katova Skala & $8.9 \mathrm{~km}^{2}$ & $474,210,983$ & $145,160,874(36 \%)$ & $118 / \mathrm{m}^{2}$ & $34 / \mathrm{m}^{2}$ \\
Jasenové- Vyšehrad & $15 \mathrm{~km}^{2}$ & $671,143,747$ & $253,083,224(37 \%)$ & $59 / \mathrm{m}^{2}$ & $25 / \mathrm{m}^{2}$ \\
\hline
\end{tabular}



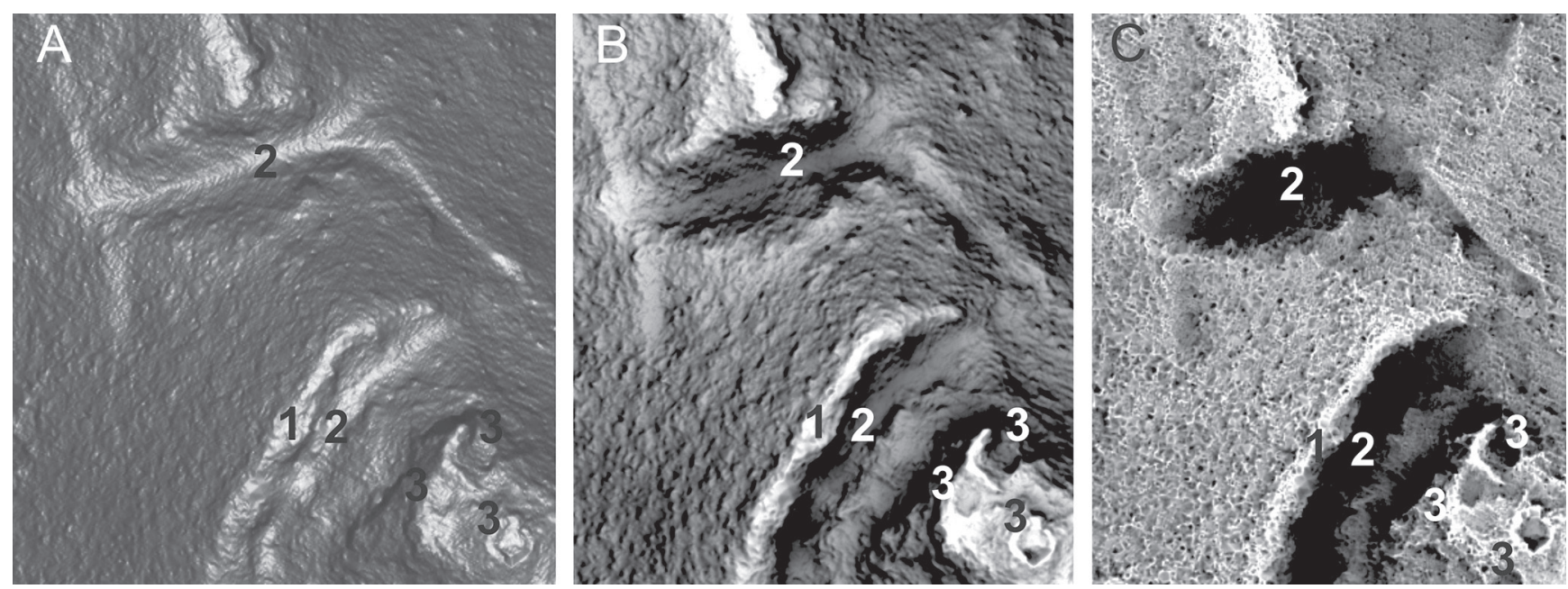

Figure 2. Visual demonstration of landscape features (site: Podhradie-Vrchmúr) using Hillshading (A), Sky View Factor (B), and Topographic Openness (C). 1 -rampart, 2 - ditch, 3 - terrain marks of masonry.

in the classification (cloth resolution, maximal iteration and classification threshold). As for cloth resolution, which refers to the grid size (the unit is the same as the unit of point clouds) of the cloth that is used to "cover" the terrain virtually, the value $0.2 \mathrm{~m}$ turned out to be of a sufficient resolution to achieve a compact DTM. Putting this value too high (according to our experience, a threshold above $0.8 \mathrm{~m}$ ) may cause too coarse a DTM. Classification threshold refers to the threshold used to classify the point clouds into the ground and non-ground parts based on the distances between points and the simulated terrain. As the study sites represent a steeply-forested environment, it was necessary to adopt smaller values $(0.2-0.4 \mathrm{~m})$ in order to filter out dense low vegetation (e.g. small bushes). Small values generate smoother DTM but on the other hand can cause misclassification of ground points as non ground ones especially when the density of the point cloud is not big enough. This may lead to data gaps in DTM. Using this procedure, approximately 80 percent of the unclassified point clouds were correctly classified as ground points. However, around 20 percent of non ground points were incorrectly defined as ground points. These points had to be filtered out manually. For this operation SW Global Mapper, LiDAR module was applied. Table 1 shows the relatively coherent results for the amount of filtered ground points. The lower value in the case of the „Vrchmúr" site may be due to the fact that this area was fully covered with a dense tree canopy unlike the two other sites where forest-free parts of the landscape were also present (see next section).

Linear triangulation (creation of a TIN surface) in the software Global Mapper 17 trial version ${ }^{3}$ was used to create the DTM out of the filtered ground points with a resolution of $0.3 \mathrm{~m} / \mathrm{cell}(\mathrm{px})$.

For the purposes of a better identification of anthropological surface features, special raster data visualization methods were subsequently applied on the created DTM, each of

\footnotetext{
http://www.bluemarblegeo.com/products/global-mapper.php
}

them enhancing its visualisation in a certain way, namely Hillshading, Sky View Factor and Topographic Openness. All of them were conducted in the open-source software SAGA GIS ${ }^{4}$. Basic visual inspection of a particular DTM was done with the help of Hillshading (e.g. Devereux et al. 2008; Challis et al. 2011). When setting the parameters of this algorithm, it turned out to be useful to use a vertical altitude angle of illumination in order to diminish possible visual biases caused by deep shadows that may hide important landscape features. Vertical simulated light direction does not cause too deep shadows but on the other hand enhances plasticity of the surface sufficiently enough so that all terrain features are visible. The prime benefit of this visualisation approach is a very easy and quick application procedure. In this regard, Hillshading delivered a brief overview of the inspected landscape that enabled basic natural and anthropological features to be detected and acquire a notion of the whole landscape structure. For a better visual investigation of the anthropological as well as natural terrain marks, it was necessary to apply Sky View Factor (Kokalj et al. 2011) and Topographic Openness (Yokoyama et al. 2002; Doneus 2013). Both algorithms significantly improved the visual notion of concave convex surface transitions, which clearly highlighted all man-made earthworks, such as fortifications, where the top of ramparts were visualised as bright areas whereas ditches and slopes of ramparts were depicted with different levels of dark shading. Similarly, under both mentioned visualisations, historical routes became more obvious: the bottom parts were drawn in "dark", making them easily distinguishable from the surrounding landscape. Besides that, the Topographic Openness particularly magnified the visual awareness of terrain remnants of former masonry structures, as the absence of surface elevation in this mode stressed the topographic aspects of the landscape with a trend towards a clear delineation of its parts (Figure 2).

\footnotetext{
${ }^{4}$ http://www.saga-gis.org/en/index.html
} 


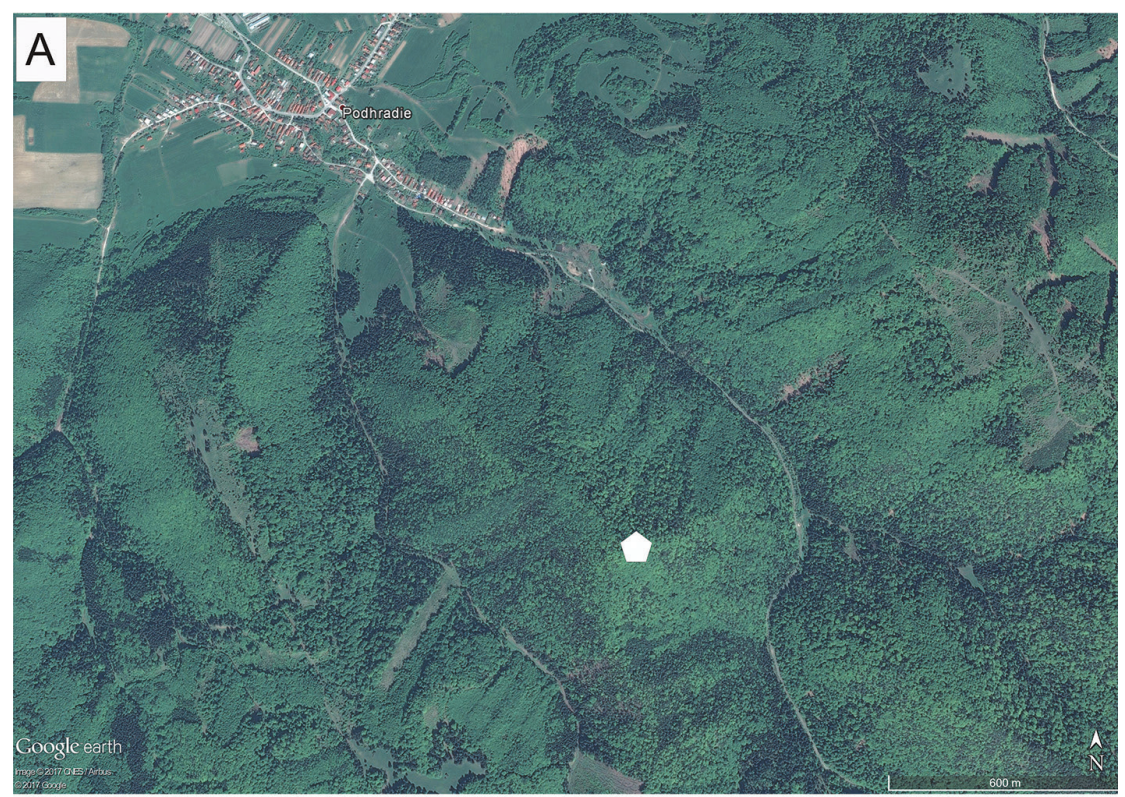

Figure 3. Location of the centres of the case study sites and a visual demonstration of their landscape environment on Google Earth. A: PodhradieVrchmúr, B: Sklabinský Podzámok - hillfort "Katova Skala", C: Jasenové/Nitrianske Pravno hillfort "Vyšehrad".
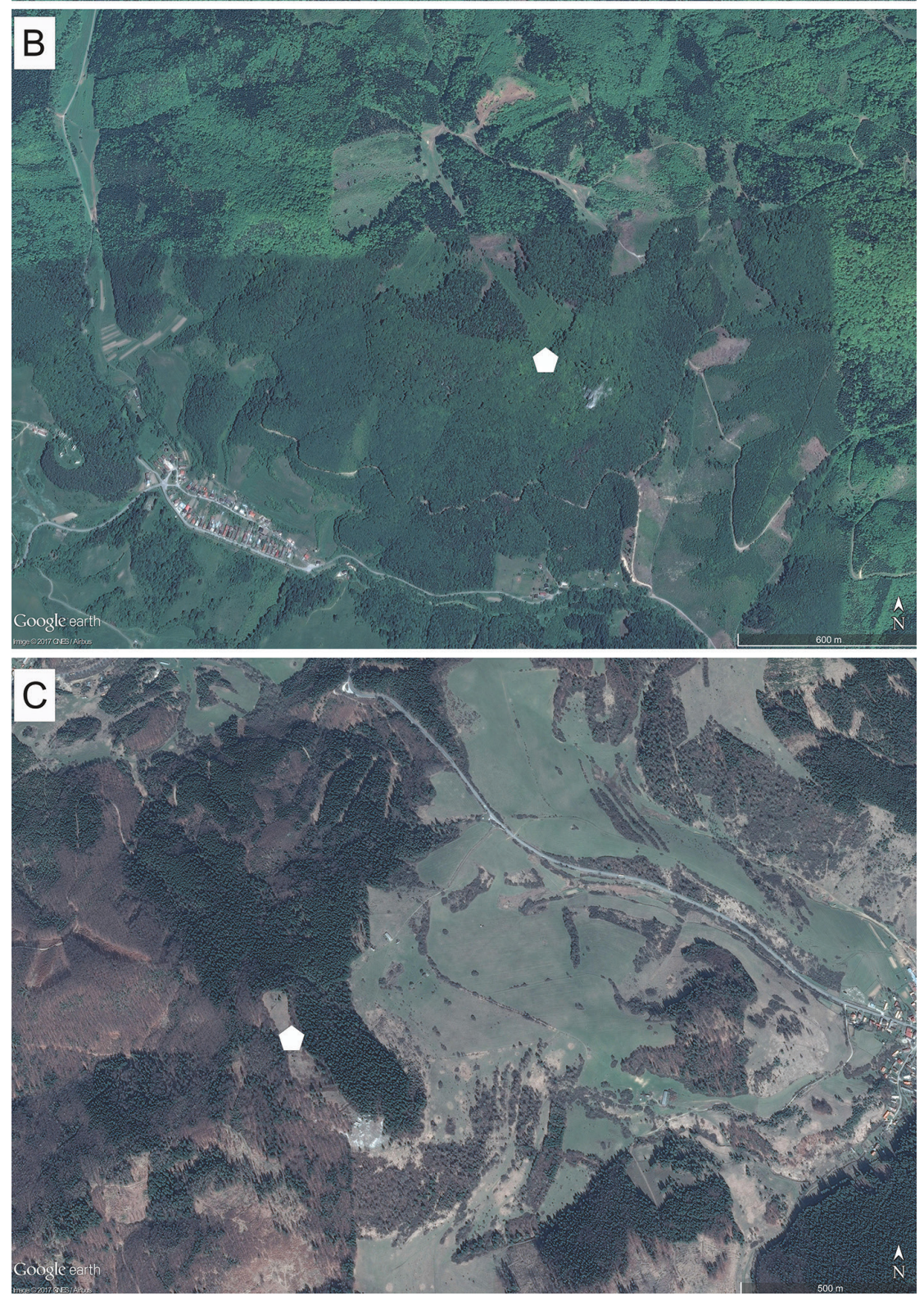
For both algorithms, the search radius and number of search directions have to be set. These are the parameters that can determine the resulting outcome of a procedure significantly. In our case, 16 search directions and a 10-m search radius turned out to meet our demands for best identifying small- and medium-scaled anthropomorphic features. For visualisation purposes, standard deviation histogram stretch was applied.

The final step in the workflow was the archaeological interpretation of the visualized DTM. This included the detection and subsequent interpretation of anthropological surface features. An inevitable part of the data interpretation was ground truthing (verification), which prevented the false (anthropological) interpretation of purely natural relief features. Ground verification was also needed for a better understanding of the detected anthropological features: in order to distinguish an historical anthropogenic surface from the remnants of current human activities. In general, dotted concave or convex objects are the most difficult to detect and interpret. Especially in this category there are many possible misinterpretations of pseudo-archaeological features represented by tree boles, accumulations of fallen tree branches as an outcome of forestry, and other modern man activities. Finally, a global graphical (vector) interpretation of all detected anthropomorphic features was made.

\section{Case studies}

\subsection{Podhradie - Vrchmúr, Slovakia}

The site "Vrchmúr" is situated on a rocky hilltop - the highest spot height of the hill "Smrekové" (872 m.asl.), which forms part of the Vel'ká Fatra mountain range (north-western Slovakia). The hill has a prolonged shape in a northwest-southeast direction. The Hlavná valley, through which the Podhradský stream flows, borders it on the eastern and north-eastern side. The western foothill is surrounded by the Hradská valley with a mountain stream, which flows into the Podhradský stream in the residential area of the municipality (Figure 3A).

The site in question represents the minor remains of the so-called Sučany castle. According to current knowledge, the castle foundation can be dated to the second half of the $13^{\text {th }}$ century, with the possible builder being the Zvolen district administrator Mikuláš of the House of Balaša. The castle passed into the possession of Matúš Č́k around the year 1310, and after his death was returned to the Balaša household as their property. Under an exchange agreement, the property of Sučany together with the "stone castle" passed, in 1323, to the Zvolen district administrator Donč, whereupon the king is alleged to have taken it back in the very same year and ordered its partial demolition. Later, it was probably subject to some partial recovery as, in 1430 , the castle area become the property of Martin from Betlanovce and Juraj Thurzo, "together with the castle in the village Podhradie, called Sučany castle" (Plaček, Bóna 2007, 282). The above-ground stone architecture is currently completely removed and the layout of the castle can only be defined by means of terrain signs (rampart, ditch, etc.) It can be assumed from the perspective of the dominant position of the castle that it fulfilled a controlling function of the present long-distance road just at the place where it connected to a significant communication route leading from the Turiec basin (Plaček, Bóna 2007, 282). The castle area is covered with a dense deciduous forest.

The LiDAR sensing (Figure 4) allowed an exact identification of the whole layout of the former castle area after ground points were filtered and the DTM created. The central part is formed by a rocky outcrop, which is bordered on the western and north-western part by a massive rampart with an inner ditch (Figure 5D). A neck (or throat) ditch dividing the castle area from the main mountain ridge of the hill "Smrekové" (Figure 5E) can be seen to the northwest from the rampart. The foundations of a rectangular object with an inner dimension of $3.4 \times 3.6 \mathrm{~m}$ can be identified on the DTM in the central part of the rocky hilltop. This could be a central castle tower (Figure 5). Two rectangular terrain depressions to the north and northwest from the central rectangular building are clearly visible in the "Sky View Factor" and "Topographic Openness" visualisation (Figures 4B and 4C), which enhance the convex terrain shapes by means of significantly darker hues 5 . In addition to the aforementioned relevant archaeological objects, the DTM shows a relatively large number of point pseudo-objects represented usually by traces of forestry activities (Figure 4; such as stumps from felled trees, intentional wood dump sites) or by natural processes (such as the accumulation of pioneer plants etc.).

The terrain reconnaissance of the locality connected with the short-term terrain archaeological research was aimed particularly at the hilltop platform of the rocky hill and was performed in May and June 2016 (Horňák, Both 2016). Two probes captured the corners of the central rectangular building, probably the main castle tower (Figure 5A), represented by two lines of foundation masonry embedded in the rocky subsoil. Further probing was aimed at the northwestern depression, where the foundations of a previously unknown building with a rectangular layout were revealed. It was formed of foundation masonry, indicating a continual build-up of the area around the castle centre at this point (Figure 5B). In the case of the northern terrain depression captured on the LiDAR data, this was a rectangular area cut into the rock, which we interpreted at a working level as the castle cistern (Figure 5C).

From the point of view of monument preservation of the Sučany castle, LiDAR sensing proved to be an effective analytical tool that enabled detailed geodetic measurement of the monument, clarified its internal built-up area, and its localisation on various types of cartographic input materials. These results allowed the filing of an application to declare the Sučany castle a national cultural monument and thus contributing to its more adequate protection and, of course, its subsequent presentation to the wider public.

\footnotetext{
The Topographic Openness especially enhances terrain depressions by means of continuous very dark or black areas.
} 

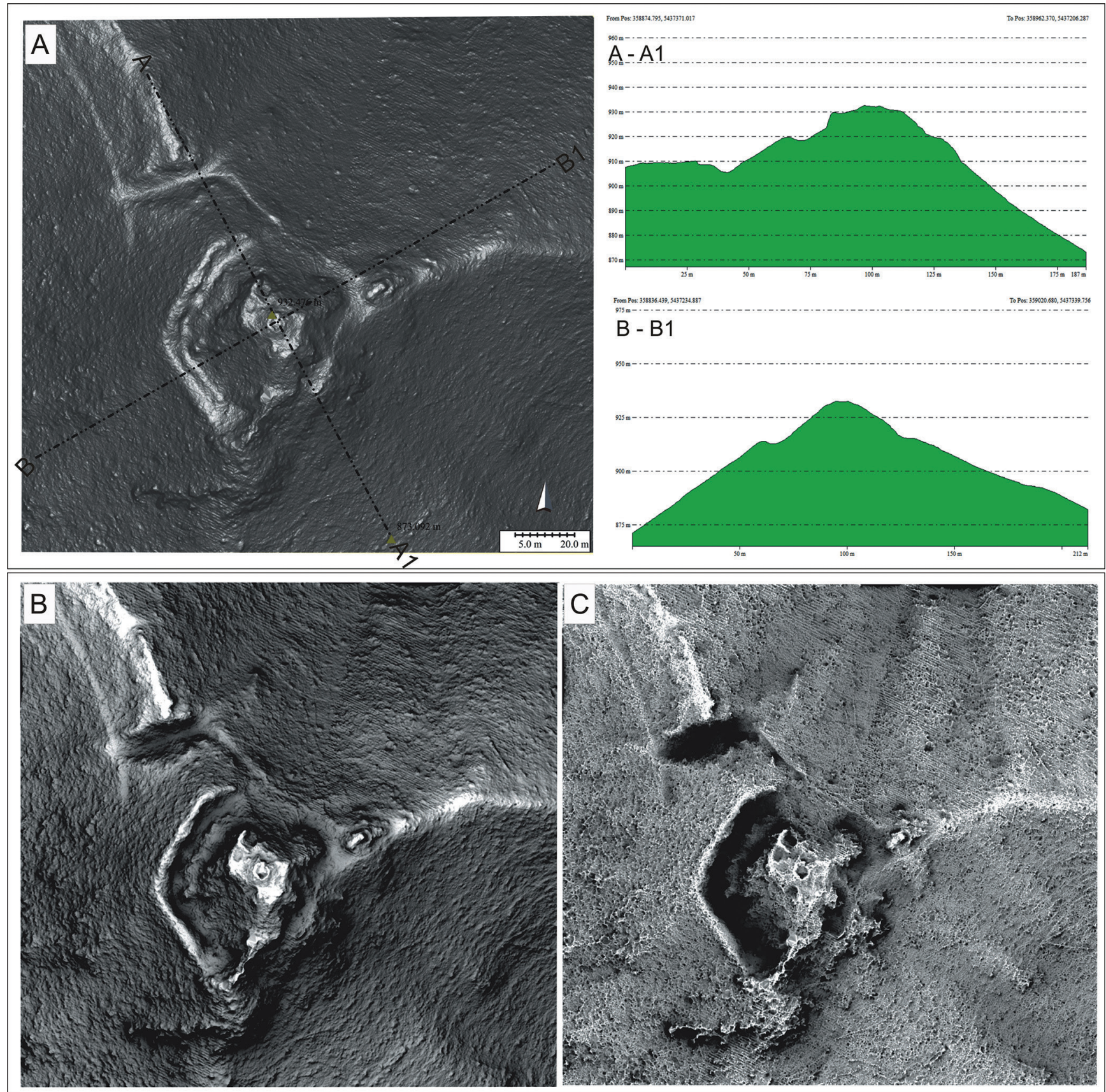

Figure 4. Podhradie - Vrchmúr. DTM (0.3 m/cell). A: Hillshading with section views, B: Sky View Factor, C: Topographic Openness.

\subsection{Sklabinský Podzámok - hillfort "Katova Skala", Slovakia}

The hillfort "Katova Skala" is situated in the northern part of the western foothills of the Vel'ká Fatra mountain range (north-western Slovakia). It is located at the top of a limestone hill named Dvoriská and Katova skala $(927 \mathrm{~m}$. asl.). The hilltop's elevation above the valleys below reaches almost $450 \mathrm{~m}$. The hillfort area is currently covered with a dense forest overgrowth (Figure 3B).

The hillfort had been almost unknown to the professional public until 1998, despite the fact that even a popular hiking trail leads there. Unfortunately, shortly after its media coverage in a local periodical the area has become an object of interest for illegal robbery. Only fragmental oral information, obtained in cooperation with the Police of the Slovak Republic, has enabled us to have an idea about the richness of this hillfort (a large amount of so-called Scythian arrow-heads, bronze ties and militaries from the Late Bronze Age up until the High Middle Ages were allegedly found here). Two hoards from the Late Bronze Age and Hallstatt culture were found in the hillfort area, or more specifically on its western slope, in 2002. In addition, fragmentary findings have been recorded from the locality, coming from the La Tène culture as well as from the High Middle Ages, which are associated with the existence of a medieval castle situated on the south-eastern outcrop of the rocky ridge 
Figure 5. Podhradie - Vrchmúr. DTM with graphic interpretation. A: Main castle tower, B: Remains of castle rectangular building, C: Cistern?, D: Rampart with inner ditch, E: Outer ditch.

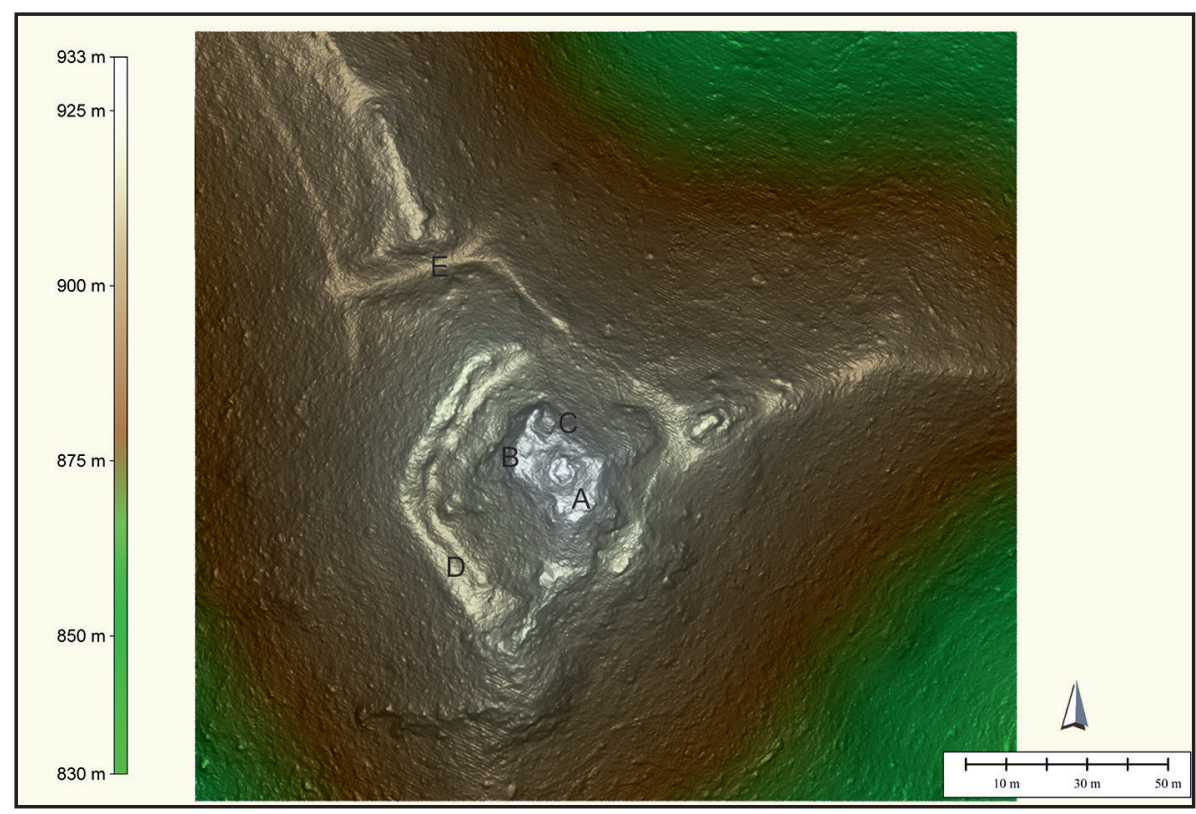

(Pieta, Veliačik 2014). A comprehensive archaeological research has not yet been performed in the locality despite the fact that this is a hillfort with an obvious central function.

LiDAR scanning of this part of the Vel'ká Fatra mountains revealed a complete topographic composition of the site (Figures 6 and 7). The area is framed on its southern part by a visible terrain ridge, with steep slopes on its southern side, which at some places becomes a rock wall forming a compact structure on the south-eastern outcrop of the ridge. Traces of a rampart and inner ditch are visible at this place, bordering the area of a smaller medieval castle from the $12^{\text {th }}-13^{\text {th }}$ century on the north-western side. The fortification of the prehistoric hillfort from the Late Bronze Age until the Iron Age connects to the small castle to the northwest. Its area has a prolonged shape in a northwest-southeast direction. It is bordered by the edge of a steep slope on its southern side. Traces of a rampart are visible on the northern side, which copies the terrain morphology, closing here the inner area of the hillfort. A protracted elevation rises in its eastern part with a longitudinal north-south orientation. A separate longitudinal space bordered on all sides by partially-eroded ramparts is separated from the main area on the western side by means of an indistinctive rampart. Two distinctive terraces are situated to the north of the hillfort. The third (inner) less distinctive terrain modification is adjoining the terrain edge visible in the eastern part of the hillfort. It is partially lined by a terrain elevation, probably a rampart, on the outside. The perimeter of the hillfort is lined on the eastern side
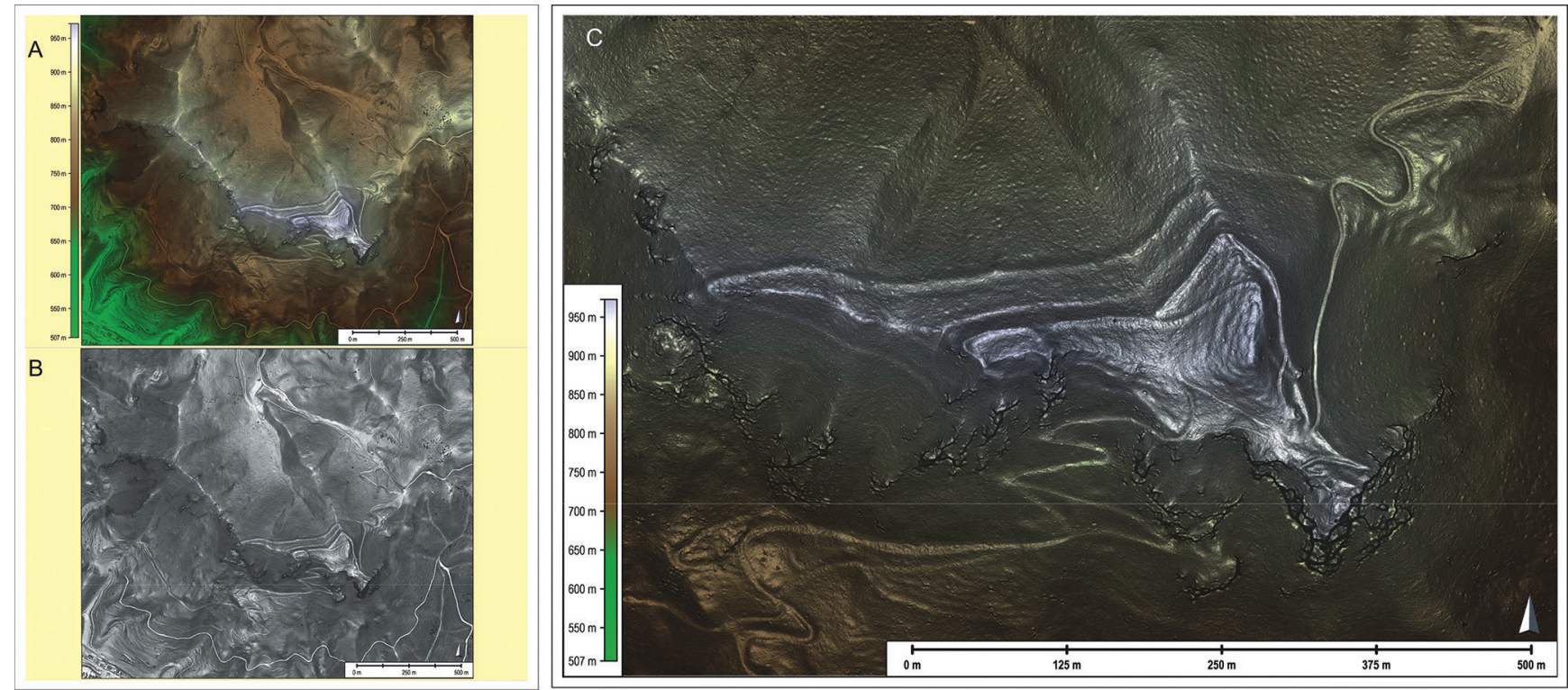

Figure 6. Hillfort "Katova Skala". DTM (0.3 m/cell). A: Hypsometry in combination with hillshading of the hillfort within a broader landscape frame, B: Hillshading visualisation of the hillfort within a broader landscape frame, C: Hypsometry in combination with hillshading of the hillfort itself. 


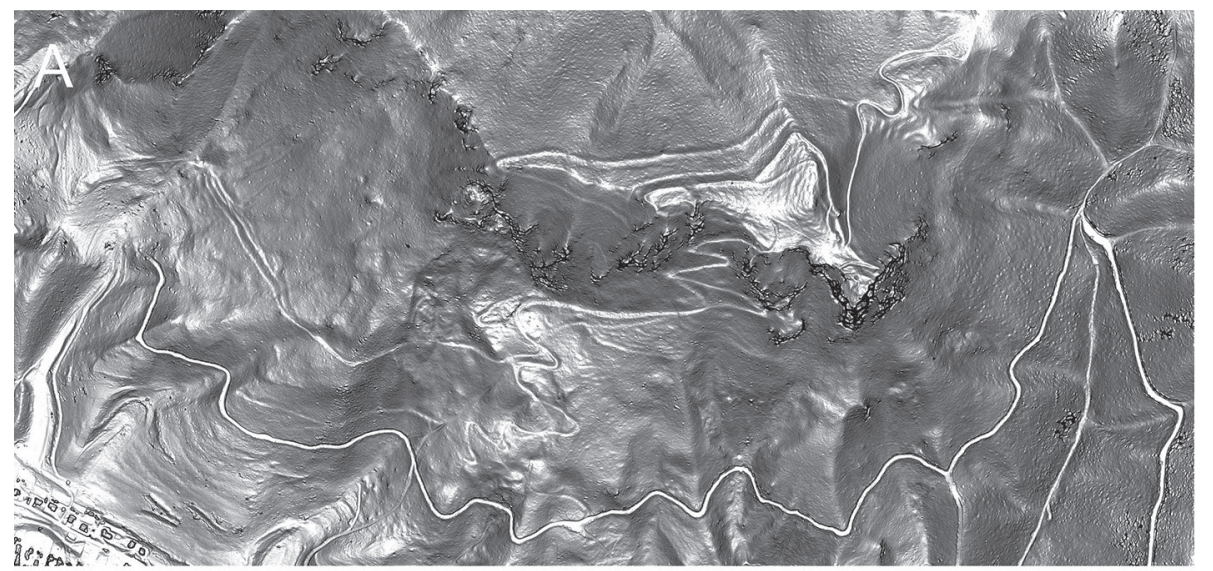

Figure 7. Hillfort "Katova Skala" and neighbouring landscape. DTM $(0.3 \mathrm{~m} / \mathrm{cell})$. A: Hillshading, B: Sky View Factor, C: Topographic Openness.
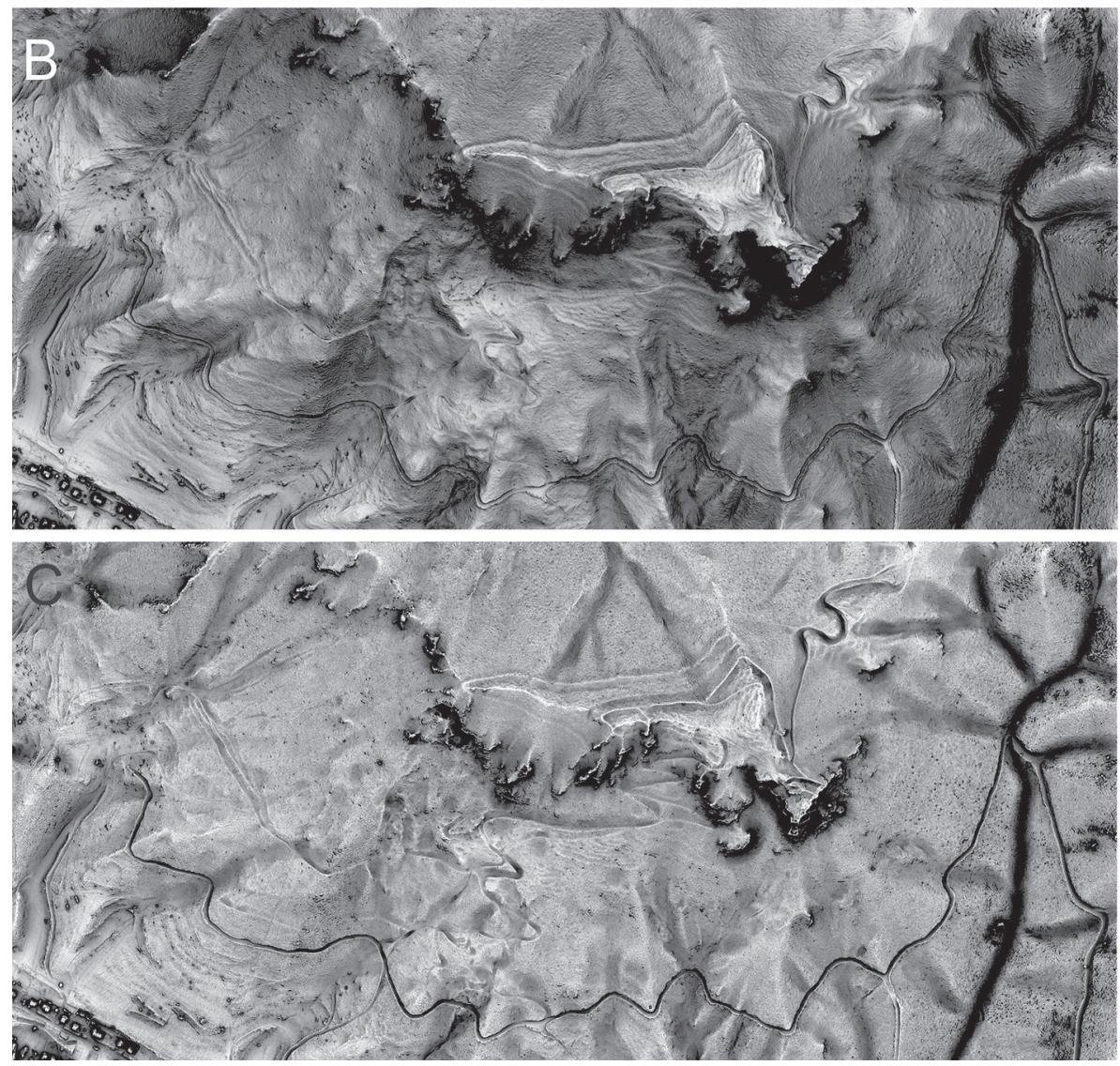

with a number of terrain modifications forming a narrow discontinuous stripe "cut" into the terrain. The dating of these terrain forms is unclear. They can also represent recent communication modifications of the terrain (Figure 8).

There are currently two communications leading to the site, which are also easily visible on the LiDAR images. One leads up steep southern slopes from Sklabinský Podzámok and the other serpentine road leads from Podhradie into the area from the eastern side. We assume that they both are of prehistoric or medieval origin (Figure 8).

LiDAR sensing has brought a new view of the hillfort's complexity. In addition to defining its background, consisting of systems of settlement terraces, several access communications of prehistoric or medieval origin were also found. The area size of the hillfort was clarified and its geodetic measurement on a cadastral map was also made, which was the last input material needed to allow the Regional Monuments Board in Žilina to start proceedings with regard to the declaration of the hillfort as a national cultural monument.

\subsection{Jasenové/Nitrianske Pravno - hillfort "Vyšehrad", Slovakia}

The hillfort Vyšehrad has a very important position in the cultural awareness of the inhabitants of the Turiec Basin and Upper Nitra Region (north-western Slovakia). This is certainly caused by its distinctive location dominating both regions. The hillfort itself is situated on the top of the Vyšehrad hill massif (with an area of around $20 \mathrm{~km}^{2}$ ), which is situated in the Žiar mountains on the transition from the 
Figure 8. Hillfort "Katova Skala". Vectorised interpretation of landscape features.
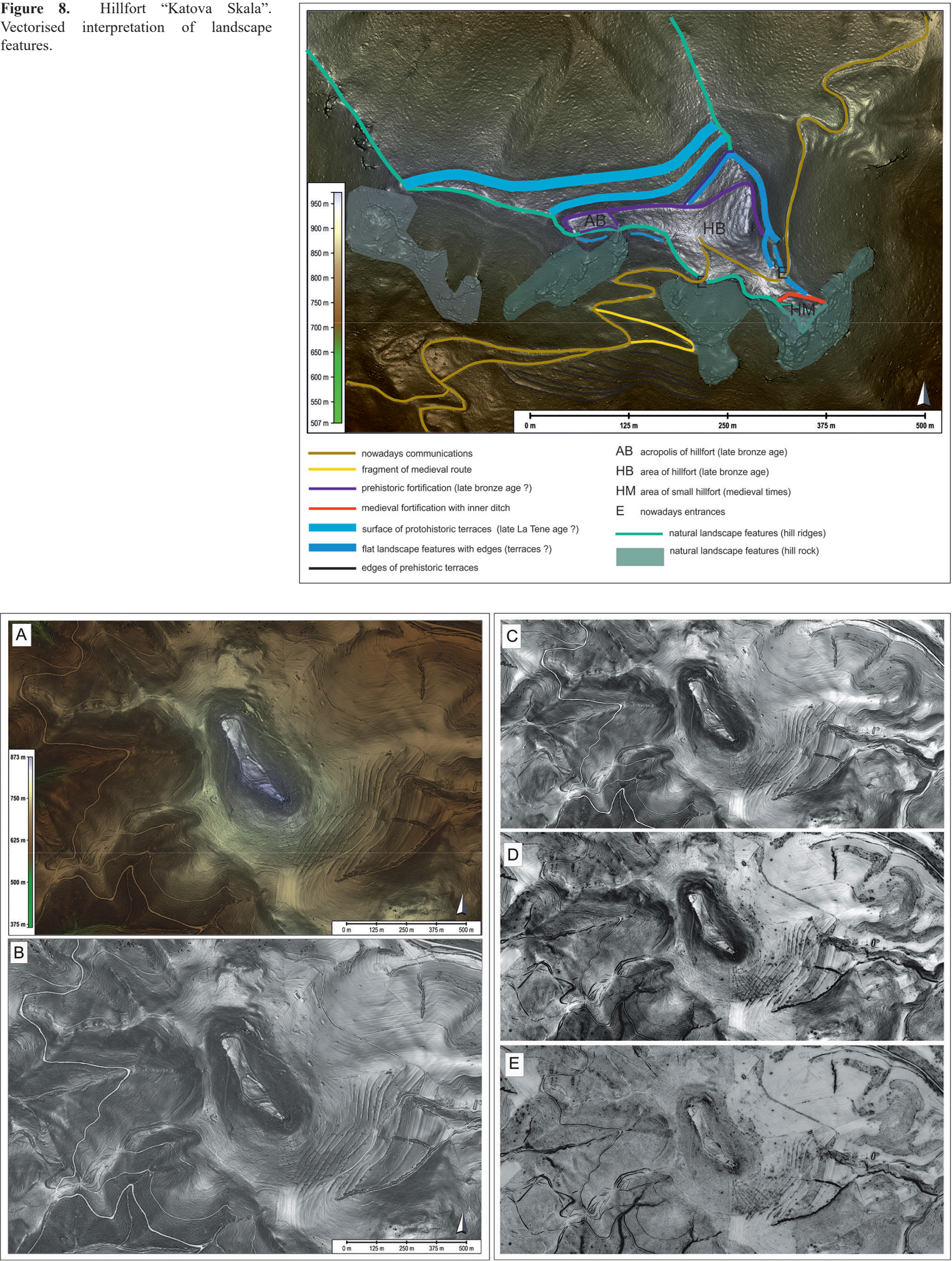

Figure 9. Hillfort "Vyšehrad" within a broader landscape frame. DTM $(0.3 \mathrm{~m} / \mathrm{cell})$. A: Hypsometry in combination with hillshading, B: Hillshading, C: Hillshading with standard deviation histogram stretch, D: Sky View Factor, E: Topographic Openness. 


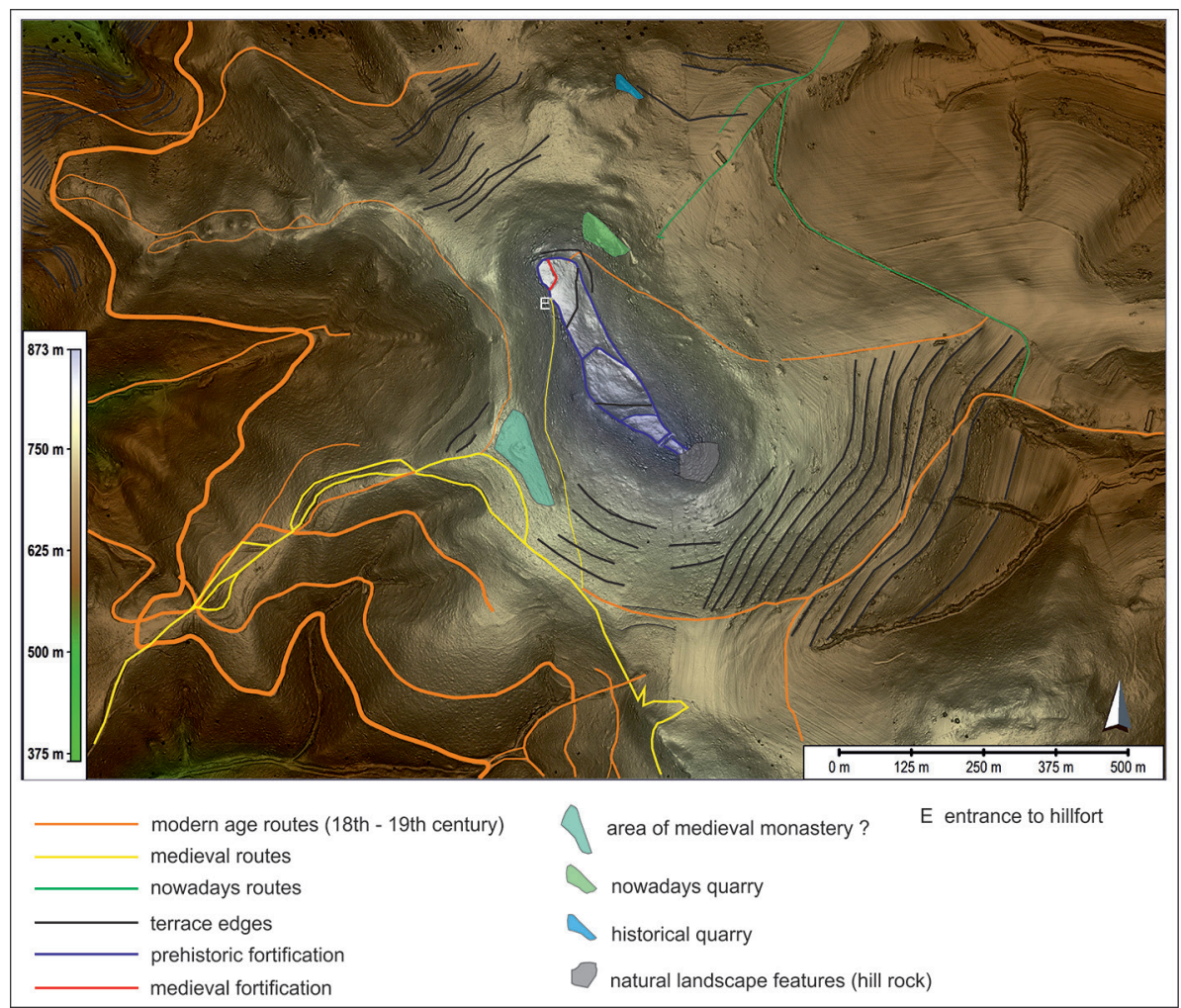

Figure 10. Hillfort "Vyšehrad". Vectorised interpretation of landscape features.

mentioned Turiec Basin into the Upper Nitra valley. An intensive forest overgrowth covers most of the hill slopes, whereas the very hilltop as such is relatively "open" with occasional concentrations of trees and low vegetation (Figure 3C). The south or south-eastern slope is formed by rock. There are several small fluvial valleys and forest roads of various age cut into the massif.

Knowledge of the chronology of the hillfort comes mainly from the archaeological research of the Upper Nitra Museum in Prievidza, performed in the 1970s and 1980s (Remiášová $1977 ; 1980 ; 1981)$. The research results confirm a significant settlement in the Late Bronze Age, when the hillfort was probably founded. The second phase of settlement is associated with the Iron Age, when the hillfort was resettled by the Púchov culture. The most recent settlement phase is represented by medieval settlement at the beginning of the $9^{\text {th }}$ century. In the $12^{\text {th }}$ and $13^{\text {th }}$ century, Vyšehrad was the property of the noble House of Diviacky, who owned it until 1252. It subsequently passed to the possession of the Prepositure in the nearby Kláštor pod Znievom (monastery). The settlement in Vyšehrad then disappeared under rather unclear circumstances, and except for only a short episode during the middle of the $15^{\text {th }}$ century when a small castle was built here by military groups known as "Bratríci", it was no longer settled permanently. Archaeological research was renewed by the company VIA MAGNA Ltd. in 2015 and 2016. Research activities performed within the framework of the CONPRA project were aimed at a reconnaissance of the La Tène Age and medieval cultural landscape and a probing survey of the former medieval monastery (Horñák 2016).
The LiDAR sensing proved to be the most adequate methodological procedure for understanding and observing the intensity of anthropogenic modifications from the various time periods. It was used for a detailed description of not only the internal structure of the hillfort, but more so of the significantly structured historical landscape representing its background (Figures 9 and 10). In addition to a significant concentration of historical terraces on the eastern side of the site, it particularly concerns the relatively complicated network of forest roads visible, especially on the western and south-western side of the hillfort. An extensive terrace with a significant terrain edge and structured terrain morphology is visible on the scans of the foothill of the south-western slope. A subsequent terrain reconnaissance that took place in June-August 2016 allowed a chronological determination of the detected terrain modifications in the period of the High Middle Ages, modern times and the $20^{\text {th }}$ century.

\section{Conclusion}

On the basis of the presented case studies, we can state that LiDAR represents an effective analytical tool with a wider scope of application in both the spheres of archaeological research and the agenda of heritage protection. The possibility of a clearer understanding of the structure and degree of preservation of historical cultural landscapes in the form of various types of relief digital models (hillshade, sky view factor, etc.) provides us with a unique opportunity from the perspective of applying preventive approaches to its protection, or setting such conditions of landscape cultural 
heritage regulations that will assure that these landscapes will not be interfered with at all, or failing that, will make such interference as sensitive as possible. At the same time, it is necessary to realise that the results of LiDAR sensing record all the terrain elements, whether of anthropogenic origin or not, thus making the dating of such elements an additional issue. Therefore, if interpretation of LiDAR sensing is to be carried out with responsibility, a terrain reconnaissance and verification is required in order to grasp some notion of the cultural landscape features from the autopsy. Here, the following question should be posed: if the subsequent terrain prospection still remains necessary, then does LiDAR really differ from the older topographic approach? Based on the results of our presented research of hillforts in mountainous areas of north-western Slovakia, we can state that LiDAR allowed us to observe an area of several square kilometres with several prehistoric or medieval terrain modifications (fortifications, terraces, roads, etc.), in various states of preservation, in a much more efficient way. This set of settlement activities was precisely geodetically measured thanks to LiDAR, and thus enabling the utilisation of the obtained data by a wider lay public (urban associations, local self-governments, etc.); hence it will be possible for such public bodies to arrange their planned activities in real space without, or with only a minimum, need for interference with the preserved cultural landscape. The absence of such spatial measurements has been a significant factor in the past, thanks to which it was not possible to declare hillforts to be cultural heritage monuments and thus provide for their legal protection. The additional scientific value of LiDAR data lies in the many possibilities for its application in modern analyses of settlement changes and the dynamics of prehistoric and historical societies.

In conclusion, we would like to express our confidence that this article will contribute to an understanding of the importance of LiDAR sensing in the process of preventive archaeology in those countries where this type of nondestructive technology has not yet been applied, or where its availability has been limited - not only to the scientific community but also to the non-professional public.

\section{Acknowledgements}

This project was supported by Marie CurieAction IAPP project "Contributing the preventive archaeology: Innovativeness, development and presentation, no. 324508". The flights were carried out within the project FP7 Marie Curie action IAPP: Contributing the Preventive Archaeology: Innovativeness, Development and Presentation ("CONPRA").

\section{References}

BOFINGER, J., HESSE, R. 2011: As far as the laser can reach... Laminar analysis of LiDAR detected structures as powerful instrument for archaeological heritage management in Baden-Württemberg, Germany. In: Cowly, D. (Ed.): Remote sensing for archaeological heritage management. EAC occasional paper No. 5, 161-172.

DEVEREUX, B. J., AMABLE, G. S., CROW, P. 2008: Visualisation of LiDAR terrain models for archaeological feature detection. Antiquity 82, 470-479.

DONEUS, M. 2013: Openness as Visualization Technique for Interpretative Mapping of Airborne LiDAR Derived Digital Terrain Models. Remote Sensing 5/12, 6427-6442.

DONEUS, M., BRIESE, C. 2006: Full wave-form Airborne Laser Scanning as a tool for archaeological reconnaissance. In: Campana, S., Forte, M. (Eds.): From space to place. Proceedings of the 2 nd international workshop on Remote Sensing in archaeology, CNR, Rome, Italy. BAR, International Series, Oxford Archeopress, 99-106.

DONEUS, M., BRIESE, C., FERA, M., JANNER, M. 2008: Archaeological prospection of forested areas using full wave-form airborne laser scanning. Journal of Archaeological Science 35/4, 882-893.

DONEUS, M., BRIESE, C. 2011: Airborne laser scanning in forested areas - potential and limitation of an archaeological prospection technique. In: Cowly, D. (Ed.): Remote sensing for archaeological heritage management. EAC occasional paper No. 5, 59-76.

GOJDA, M., JOHN, J. (Eds.) 2013: Archeologie a letecké laserové skenovani krajiny (Archaeology and airborne laser scanning of landscape). Katedra Archeologie, Západočeská univerzita v Plzni, Plzeň.

HESSE, R. 2010: LiDAR derived local relief models: a new tool for archaeological prospection. Archaeological prospection 17, 67-72.

HOLUBEC, M., BOBÁL', P., HRONČEK, S., BIROŠÍK, F. 2016: Využitie leteckého laserového scanovania pre potreby archeologického prieskumu. Symposium GIS Ostrava 2016. Geoinformatika pro společnost. Available online at: http://gisak.vsb.cz/GIS_Ostrava/GIS Ova_2016/sbornik/papers/gis201656ab5eb5c0668.pdf. Accessed on 2017-01-17.

HORŇÁK, M. 2016: Výsledky archeologického výskumu na lokalite Vyšehrad. Výskumná dokumentácia. MS. Excavation report. Deposited: Archive of the Monuments Board of Slovakia Bratislava.

HORŇÁK, M., BOTH, M. 2016: Výskumná dokumentácia z archeologického výskumu na lokalite Vrchmúr v k.ú. Podhradie. MS. Excavation report. Deposited: Archive of the Monuments Board of Slovakia Bratislava.

CHALLIS, K., FORLIN, P., KINCEY, M. 2011: A generic toolkit for the visualisation of archaeological features on airborne LIDAR elevation data. Archaeological prospection 18, 279-289.

KOKALJ, Ž., ZAKŠEK, K., OŠTIR, K. 2011: Application of Sky View Factor for visualisation of historic landscape features in lidar-derived models. Antiquity 85, 263-273.

OPITZ, R. S.; COWLEY, D. C. (Eds.) 2013: Interpreting Archaeological Topography: 3D Data, Visualisation and Observation. Oxbow Books, Oxford.

PLAČEK, M., BÓNA, M. 2007: Encyklopédia slovenských hradov. SlovaArt, Bratislava.

PIETA, K., VELIAČIK, L. 2014: Pozoruhodné depoty zo Sklabinského Podzámku. Studia Archaeologica Brunensia 19/2, 5-26. Available online at: https://digilib.phil.muni.cz/bitstream/handle/11222. digilib/129982/1_StudiaArcheologicaBrunensia_19-2014-2_2. pdf? sequence $=$. Accessed on 2017-01-17.

REMIÁŠOVÁ, M. 1977: Hradisko Vyšehrad. Archaeologia Historica 2, 265-269.

REMIÁŠOVÁ, M. 1980: Hradisko Vyšehrad. Horná Nitra 9, 13-29.

REMIÁŠOVÁ, M. 1981: Hradisko Vyšehrad. Archaeologia Historica 6, 467-471.

RUTTKAY, M. 2015: Využitie leteckej prospekcie a skenovania pri výskume hradísk a ich zázemia na západnom Slovensku. Die Nutzung der Luftbildaufnahmen und scanning bei der Erforschung der Burgwälle und ihres Hinterlandes in der Westslowakei. In: Pieta, K., Robak, R. (Eds.): Bojná 2. Nové výsledky výskumov včasnostredovekých hradisk. Archaeologica Slovaca Monographiae Studia Instituti Archaeologici Nitriensis Academiae Scientiarum Slovacae Tomus XXVII, Nitra, 297 335.

ŠTULAR, B.; KOKALJ,Ž.; OŠTIR, K.; NUNINGER, L. 2012: Visualisation of lidar-derived relief models for detection of archaeological features. Journal of Archaeological Science 39/11, 3354-3360. 
TRIER, O. D.; PILO, L. H. 2012: Automatic detection of pit structures in airborne laser scanning data. Archaeological prospection 19/2, 103-121.

YOKOYAMA, R.; SIRASAWA, M.; PIKE, R. J. 2002: Visualizing topography by openness: A new application of image processing to digital elevation models. Photogrammetric Engineering and Remote Sensing 68, 257-265.
ZHANG, W.; QI, J.; WAN, P.; WANG, H.; XIE, D.; WANG, X.; YAN, G. 2016: An Easy-to-Use Airborne LiDAR Data Filtering Method Based on Cloth Simulation. Remote Sensing 8/6, 501. Available online at: http:// www.mdpi.com/2072-4292/8/6/501/htm. Accessed on 2017-01-17. 